\title{
Representations of Roman Catholic religious sisters' responses to COVID-19 in the Zambian media
}

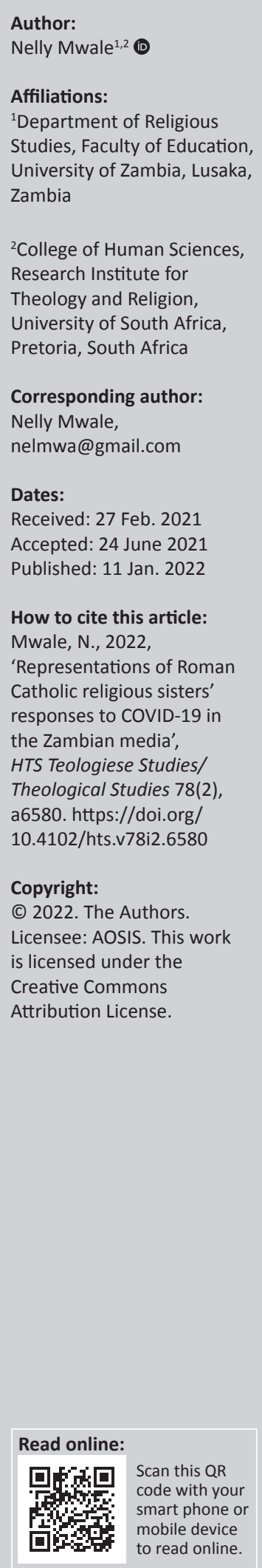

Despite the growing visibility of religious women's responses to COVID-19 in the media, the discourses of religion and the pandemic in emerging scholarship were preoccupied with the responses of churches to COVID-19, and neglected the contributions of religious women to the pandemic in Zambia. This article, therefore, explores the interface between religion and COVID-19 through the representations of the responses of Roman Catholic religious sisters to the pandemic, in the media in Zambia, from a religious health asset (RHA) perspective. The study drew on two objectives, namely, to describe the representations of Roman Catholic religious sisters' responses to COVID-19 in the media; and to explain the nature of the Roman Catholic religious sisters' responses to the pandemic as represented in the media with a focus on the utilisation of RHAs. It drew on an interpretive case study in which data were collected through content analysis. It shows that the responses of the religious sisters were covered more in Catholic related media. These responses ranged from providing key COVID-19 messages, integrating COVID-19 in the existing programmes to providing basic equipment and food to the needy communities as shaped by the utilisation of RHAs at their disposal, and as informed by their prophetic mission. The article argues that the Roman Catholic religious sisters' responses to the pandemic affirmed women's active roles in combating the pandemic.

Contribution: The article's contribution lies in adding the narratives of women's contributions to the pandemic in the early stages of the outbreak of COVID-19 to women theologies scholarship in Africa. And also, extending the utilisation of RHAs to the new pandemic and the implications it draws on the need for engendering religious responses to the pandemic by capturing women's narratives during a pandemic as part of constructing women theologies in the face of COVID-19.

Keywords: women; religion; religious health assets; COVID-19; media and Roman Catholic religious sisters.

\section{Introduction}

Although, discourses of religion and the COVID-19 pandemic were popular in public life, the contributions made by religious women to fight against the pandemic were a neglected aspect in Zambia. Using the representations of the Roman Catholic religious sisters' contributions to COVID-19 in the media, this article explores the responses of religious women to the COVID-19 pandemic in the first 4 months of its outbreak in Zambia. The article therefore, does not seek to evaluate the impact of the Roman Catholic religious sisters' responses, but rather to engage with how the responses pointed to the Catholic religious sisters' utilisation of religious health assets (RHAs) at their disposal in the context of the new pandemic. It is also worth noting that the inquiry into the religious women's responses to the pandemic is anchored on the mission of the religious sisters, which is to be at the service of the transforming mission of the Church through their differentiated provision of health, education, and other social services in the country (www. zamsisters.com, accessed on 02 June, 2021). The ultimate goal of this transformation closely resonates with some of the features of African women theologies, especially as centred on the quest for liberation from all that dehumanises humanity (Haddad 2013:13). Based on this, it was assumed that the contributions of the religious women to the pandemic would be driven by their faith and that religion would be an asset in responding to the pandemic.

The article takes the view that the narratives of the women during the pandemic were significant for constructing women as active players in the making of contemporary church history.

Note: Special Collection: Women Theologies, sub-edited by Sinenhlanhla S. Chisale (Midlands State University) and Tanya van Wyk (University of Pretoria). 
As observed by Mwaura (2015:93), historically storytelling has played a proactive role in changing the roles of women from being observers and victims into participants and actors. The article is thus deemed significant for contributing to scholarship on women theologies by exemplifying how the narratives of the responses of the Roman Catholic religious sisters to COVID-19 shaped African women theologies in the Zambian context through fostering social advocacy, recognition of human dignity, and doing service in the community by exploiting the RHAs at their disposal in a quest to promote human life. As stressed by women theologians such as Haddad (2013:13), African women theologies are characterised by a focus on social advocacy, doing service in the community, valuing women's experiences through narratives and specificity of experience. This also complements the long history of Catholic religious sisters standing alongside some of the most vulnerable communities during times of great need.

The article is also deemed to be of social significance because it situates the role of religion in the pandemic in the contributions of Roman Catholic religious sisters, given that their contributions remained obscured in the wider church responses to the pandemic. This is because the media representations of the churches responses to COVID-19 did not specifically include women's responses. In view of the fact that scholarship on RHAs has focused on HIV and AIDS and health provision in general (African Religious Health Assets Programme [ARHAP] 2005; Chitando 2007; Olivier 2011; Olivier, Cochrane \& De Gruchy 2012), the article has scholarly significance because of its focus on extending the utilisation of RHAs to the novel COVID-19 from the Zambian context.

The inquiry into the contributions of the Roman Catholic religious sisters also complements national and international emerging scholarship on the pandemic. In Zambia, this scholarship has been dominated by education-oriented studies. For example, Sintema (2020) and Mulenga and Marbán (2020) explored the effect of the pandemic on the performance of Grade 12 learners with reference to STEM subjects, and COVID-19 as a gateway for digital learning in Mathematics education. Mwale and Chita (2020) also explored the student responses to the adoption of e-learning at a public university in Zambia in the context of institutional closures in the wake of the pandemic. Internationally, studies have tended to focus on the role of religious practices in spreading the virus in different contexts such as South Africa (Jaja, Anyanwu \& Iwu Jaja 2020), Nigeria, Tanzania and Ethiopia (Lichtenstein, Ajayi \& Egbunike 2020), South Korea (Wildman et al. 2020), and the mediatisation of worship (Aluko 2020).

Additionally, the article shifts the focus from the popular emerging discourses of the impact of COVID-19 on women to the ways in which women were contributing to fight the pandemic. The focus on the impact of COVID-19 on women has largely been premised on the fact that the direct as well as the indirect impacts of public health emergencies fall disproportionally on the most vulnerable and marginalised groups in society (including women). For example, Mahuku et al. (2020:3) established impacts of the pandemic on women ranging from increased care burden as a result of schools being closed; health systems becoming less accessible with the focus being COVID-19 responses; increased risk and exposure to COVID-19 (women are at the frontline of the response as community health workers and nurses), increases in gender-based violence (GBV); reduced access to GBV support and sexual and reproductive health services; loss of income because of restrictions in movement (most women are engaged in informal trade, with no social safety nets). Coulson et al. (2020:1) also observed that COVID-19 jeopardised progress made towards protecting women and girls from violence and harmful practices. The article unfolds by giving a brief description of the Catholic religious sisters and their work in Zambia, the theoretical framework, aim and objectives, and research design and methods before discussing the Catholic religious sisters' responses to the pandemic in the media.

\section{Catholic religious sisters in Zambia}

The term Catholic religious sisters is used to refer to women in the Catholic Church who have taken public vows in a religious institute dedicated to apostolic work. As explained by Eze, Lindegger and Rakoczy (2015):

[T] he consecrated life of the Catholic Church is lived by men and women. It is marked by a life of dedication (in this particular case, women) who feel called by the Spirit to devote their entire life totally to God and evangelical counsels (vows) of consecrated celibacy (chastity), poverty and obedience, and live in community. (pp. 1-2)

\section{Accordingly:}

[T] he Catholic religious sisters follow the example of Christ as presented in the Gospels in terms of developing an intimate relationship with God in which prayer and service (work) are integral parts of their personal and religious identity. (Congregation for the Institutes of Consecrated Life and Societies of Apostolic Life 2008:5-8)

As of 2017, there were more than 2000 Catholic sisters from 42 indigenous and international congregations across Zambia (The Conrad N. Hilton Foundation's Catholic Sisters Initiative 2017:15). In terms of organisation, the congregations of Catholic religious women are affiliated to the Zambia Association of Sisterhoods (ZAS), which was established in 1958 to coordinate congregations, and take care of issues and programmes that affect Sisters (Sepeti 2008:33). The Catholic sisters work in a wide range of ministries including healthcare, education, agriculture, and other social service and income-generating activities. These ministries are located across all regions of the country. In fact, Sisters are known for serving in remote areas where the government has a difficult time recruiting and retaining staff for healthcare, education, and other state-run services (The Conrad N. Hilton Foundation's Catholic Sisters Initiative 2017:15). As spelt out by Sepeti (2008): 
[F]rom the very arrival of the first international congregation of the White Sisters, the direction and priority areas of the sisters are in the areas of teaching in schools, catechesis, hospital work and charitable work, thus the three missionary dimensions that characterise the sisters' institutions are education, evangelisation and health. (pp. 27-28)

Prior to the outbreak of COVID-19, besides their provision of education, health and pastoral activities, the Sisters were implementing different spiritual, social and developmental projects. These included: the Kalundu Study Centre (KSC), a formation and leadership institution that offers a one year Formation and Leadership course; African Sisters Education Collaborative (ASEC) Programme; Strengthening the Capacity of Religious Women in Early Childhood Development (SCORE ECD phase II); Catholic Care for Children in Zambia; Justice, Peace and Integrity of Creation, and Prayer Companion, among others (www.zamsisters.com). The work of the Roman Catholic religious sisters in the country's development has been captured by Hinfelaar (2004:222-224, 343-344) who traces how the ZAS became involved in driving the development agenda of the nation through different projects since their inception, including the specific ministries of each congregation.

Zambia reported the first COVID-19 case involving a couple that travelled to France for a short holiday on 18 March 2020. As of 25 July 2020, the country had 4328 confirmed cases of COVID-19 (Ministry of Health [MoH] 27 July 2020). In order to curb the spread of the virus, measures such as social distancing and lockdown in certain towns were implemented as supported by the Public Health Act Cap 295 of the Laws of Zambia. The prevention and control measures had implications on different spheres of life. For example, schools and places of worship were closed. Similarly other sectors of the economy were also closed. Additionally, different categories of the population were affected differently, not only by the virus but also by the preventative measures that were put in place. Different religious groups responded to the crisis in different ways. In the case of the Roman Catholic religious sisters, the onset of COVID-19 entailed a shift from their normal missionary activities to accommodate the new situation that was presented by the pandemic.

\section{Theoretical framework}

The response of religion to public health, particularly pandemics, is not new in scholarship. For example, besides the role of religion in the Cholera and Ebola outbreaks, religion was also identified as one of the multifaceted approaches through which pandemics could be addressed (Barnett \& Whiteside 2006:362). This article links religion and public health through the RHAs framework. In this framework, religion is identified as an asset which impacts on health in numerous ways. According to ARHAP (2006):

RHAs are not only values imbedded in individuals and physical facilities which are there and always available to be used, but are also situated within the adherents of any religious movement and held by religious entities for the purpose of enhancing the health and wellbeing of human being. (p. 39)
In this article, RHAs are related to the Roman Catholic faith through the work of Catholic religious women during the first 4 months of the outbreak of COVID-19 in the country.

Religious health assets are also spoken of in terms of tangible and intangible assets. The most obvious religious assets are those that are tangible, such as facilities and personnel, care or service, and material support or curative interventions. While the intangible health assets are those which are the volitional, motivational and mobilising capacities that are rooted in vital affective, symbolic and relational dimensions of religious faith, belief, behaviour and ties (ARHAP 2006:11). A typology of RHAs as developed by Cochrane, Schmid and ARHAP (2004:5-6) also include: infrastructures, funding agencies, and healers (tangible with direct impact); prayer, health seeking behaviour and relationship for care (intangible with direct impact); choirs, rituals, and leadership skills (tangible with indirect impact); and faith, time, and power (intangible with indirect impact). ARHAP (2006) also affirm that:

[T] he more intangible RHAs that can offer great potential for impacting health in Africa include volunteerism and education, or behaviour changes and the building of social capital, through seemingly mundane experiences such as singing in a choir regularly, or through the ways in which religious involvement engenders hope or resilience. (p. 11)

Different scholars have utilised RHAs framework to study the role of religion in health. In this scope, the work of the ARHAP stands out. The ARHAP, which belongs to International Religious Health Assets Program (IRHAP), was started in 2002 as an initiative of interested scholars in the field of religion and health. The ARHAP conducted numerous studies in different African countries to map out the role of RHAs including South Africa, Lesotho, Zambia, Kenya, Uganda, Malawi, the Democratic Republic of Congo and Mali, with recommendations for continued mapping of the contributions of religious entities to health (Iyakaremye 2015:24-25). Additionally, the utilisation of the RHAs has also been linked to HIV/AIDS. For example, the ARHAP (2006) focused on mapping, understanding, translating and engaging RHAs in Zambia and Lesotho in support of universal access to HIV and AIDS treatment, care and prevention, while other scholars such as Iyakaremye (2015:23) problematised the neglect of religious assets in responding to HIV and AIDS.

Other women scholars such as Landman (2005) have related to RHAs with reference to spiritual care-giving to women affected by HIV or AIDS. Matibelo (2007) also analysed the impact of faith-healing Pentecostal churches on health and well-being among health-seekers in Ndola (Zambia), while Kabwe (2008) focused on the local churches and health in Zambia. Clearly, RHAs were critical in public health, especially in addressing stigma associated with HIV and AIDS, and fostering behavioural change in different communities (ARHAP 2006; Haddad 2011). Hence, it became worthwhile to explore how the Roman Catholic religious sisters responded to COVID-19 through the lens of RHAs 
and in turn extended the utilisation of RHAs in public health to counter COVID-19.

\section{Aim and objectives}

The aim of the study was to explore how the Roman Catholic religious sisters' responses to COVID-19 in Zambia were represented in the media.

The objectives are two-fold, namely; to describe the representations of Roman Catholic religious sisters' responses to COVID-19 in the media; and to explore the nature of the women's responses to the pandemic with reference to the utilisation of religious assets.

\section{Research design and methods}

The article draws on the insights from a qualitative interpretive case study because the nature of the research question was exploratory. Mouton (2001:149) stresses that case study research is appropriate for descriptive and exploratory studies.

\section{Study setting, population and sampling strategy}

The study was situated in the work of the Roman Catholic religious women congregations whose origin is traced to the arrival of the first Catholic missionaries in 1890, and the growth of the Catholic Church in Zambia (Hinfelaar 2004). It is also located in the context of the early stages of the outbreak of COVID-19 in Zambia.

The Roman Catholic congregations of sisters in Zambia were purposively selected following the recommendations by Kothari (2004:56) that non-probability or purposive sampling is more appropriate in interpretative case studies. In purposive sampling, the researcher purposely selects a particular section of the wider population to include in or exclude from the sample (Cohen, Manion \& Morrison 2007:110). Accordingly, the Roman Catholic religious sisters as an entity were purposively chosen based on the focus of the research question. As stressed by Cohen et al. (2007:114$115)$, in non-probability sampling, the selection is based on the typicality or possession of the particular characteristics that are being sought.

The selection of the Catholic congregations of sisters was also not for purposes of generalisation, but for providing depth into how women were contributing to combating the COVID-19 pandemic. In so doing, it is acknowledged that the Catholic religious sisters were not the only women who responded to the pandemic, and thus they are merely used to exemplify how women were making a difference during the pandemic. In this regard, although all congregations of Roman Catholic religious sisters were of interest to the study (as the focus was not on any individual congregation, but on Roman Catholic religious sisters in general), it is also acknowledged that not all the 42 congregations of the Roman Catholic religious sisters responded to the pandemic in a similar manner. Ultimately, the selection consisted of those
Roman Catholic religious sisters' congregations which either made their responses public or their responses were publicised by different media houses. These included: the Dominican Missionary Sisters of the Sacred Heart of Jesus, Franciscan Missionary Sisters of Assisi, Franciscan Missionaries of Divine Motherhood, Teresian Sisters, Sisters of Mercy, Little Servants of Mary Immaculate, Daughters of Mary Help of Christians, and Sisters of St John the Baptist. Therefore, the findings of the study were not for purposes of generalisation but for providing a window through which the responses of the Roman Catholic religious sisters to the pandemic could be understood.

Similarly, the context of the Roman Catholic congregations of sisters in the media sphere was shaped by the lockdown measures which called for adopting data collection methods best suited during the pandemic. In this regard, the concept of media was limited to its technological uses as a conduit for communication. On this subject, the media acts as a channel for communicating information. The media sphere is characterised by numerous forms of media, both print and online, including television, radio and social media. The ownership of the media platform also falls into public and private, with religious entities such as the Catholic Church having their own media services with both local and international reach.

\section{Data collection and analysis}

The primary method of data collection was content analysis in the form of documents, letters, press statements, photographs, institutional reports and newspaper articles. The content analysis was also grounded in different forms of media, such as television, newspapers, and photographs in the public space. Additionally, social media was also used as a supplementary source of data. As observed by Hackett et al. (2014:67-72), social media was an area of research just as religious websites were dynamic archives of religious worlds. The responses of the Catholic religious sisters which were in the public sphere were captured by different media platforms, either as interviews with the sisters by the media houses or as stories shared in the media by the Catholic religious sisters themselves. Therefore, these responses were deemed to be credible. Additionally, the guidelines on quality control formulated for handling documentary sources by Scott (1990:6) relating to authenticity, credibility, representativeness, and meaning were adhered to. Data were collected between the months of March and July 2020, and the content analysis was guided by research questions centred on the objectives and overall aim of the study.

Data were inductively analysed using the general framework for interpretive qualitative research suggested by Barker et al. (2002:219-244). The data were thematically analysed through a search for common themes that transcended the data alongside an interpretation of the themes. This involved the generation and application of codes to the data, and the identification, analysis and report of patterns (themes). 
Ethical considerations relating to consent, confidentiality and privacy as emphasised by social research scholars such as Bryman (2004) were adhered to.

\section{Findings and discussion}

The findings and discussion are based on two major emerging themes related to the objectives of the study, namely, the representation of Catholic religious sisters' responses to COVID-19 in Zambia and the nature of the Catholic religious sisters' responses to the pandemic in the media in Zambia.

\section{Representation of Catholic religious sisters' responses to COVID-19 in Zambia in the media}

The responses of the Roman Catholic religious sisters to COVID-19 in Zambia were covered by both the Catholic related media as well as the public forms of media. Although, the contributions of the religious sisters were more popular in the Catholic related forms of media, for example, only one non-Catholic related form of media (the Daily Newspaper) covered the work of the religious sisters during COVID-19 (Manyinda, Daily Nation, 'Catholic Sisters aid Street Kids' 27 April 2020). While this could easily be aligned to the fact that the media in Zambia have their own agency and choose what to publish and how it should be framed (Mwale \& Chita 2016:43), this scenario also affirmed the conclusions drawn by Geertsema (2008:1) from the South African context that women had not yet achieved equal access and representation compared to men; they were under-represented as reporters, news sources, and audience members. As such, as opposed to the contributions of religious males during the pandemic that attracted the public media attention (Mwale Zambia National Broadcasting Corporation 14 April 2020; Chakwe The Mast Newspaper, 17 April 2020; Nkomeshya News Diggers 25 April 2020), the work of the Catholic religious sisters in the media remained popular in Catholic related media. The limited coverage of Catholic religious sisters' in public media ignites the concerns of African women theologies, especially as centred on bringing to the fore the lived stories of women. As advanced by Kanyoro (2002:23), the stories of women are a basis for theology; they help to make connections between faith and action because they make use of experience and reflection as the intervals of connection.

Most importantly, the representation was largely made by the Catholic religious sisters and Catholic media services, in which case, the coverage was focused on what the religious sisters were doing during the pandemic in ways that portray the self-representation of their work. This pointed to how the religious sisters tapped into their religious assets in the form of radio and media services to communicate the ways in which they were responding to the pandemic, thereby affirming the tangible assets which religious groups possess (ARHAP 2006; Chitando 2007; Olivier 2011). Besides the utilisation of their RHAs in the form of radio and other media platforms, the dominance of the representation made by the Catholic religious sisters also pointed to tapping into their tangible asset in the form of personnel as exemplified by ARHAP (2006:11) that the tangible assets included facilities, personnel and resources. While the acknowledgment of the financial funders could not be detached from the quest to gain public confidence, it is also in line with Prempeh's (2020:2) observation that since the religious groups get funding largely from their congregants, advertising their charity work online was one way of demonstrating the use to which they put the financial contributions. The ability to find funders who could support their cause was also a pointer of tapping into funding agencies which Cochrane, Schmid and ARHAP (2004:5-6) identify as a tangible RHA which has a direct impact on health.

\section{The nature of the Roman Catholic religious sisters' responses to COVID-19 in Zambia}

The Catholic religious sisters were represented as contributing to the fight against the pandemic through numerous ways that reveal their way of providing service in the community and tapping into their RHAs. These themes were largely centred on mediatised public health awareness, integration of COVID-19 messages in existing programmes, and donations to needy communities and groups of people. This section also addresses the RHAs which were exploited by the Catholic religious sisters, and what informed the actions of the Catholic religious sisters in their responses to the pandemic.

\section{Mediatised public health awareness}

One prominent narrative was the Catholic religious sisters' engagement in public health awareness in which they mediatised the awareness campaign. In this case, working through the ZAS to organise and manage the on-air information campaign, the sisters were using radio to provide information on the pandemic through the radio show known as COVID-19 awareness programme (hosting two or three sisters, each of whom uses one of the local dialects spoken in the country.) Gandiru, in the National Catholic Register (23 July 2020), reported:

Sisters from six congregations teamed up and took to local airwaves to bolster their government's efforts to combat COVID-19. On radio and on the ground, the sisters are reaching out to communities in rural areas where there is little access to information. The campaign that was spearheaded by the Dominican Missionary Sisters of the Sacred Heart of Jesus was joined by the Franciscan Missionary Sisters of Assisi, Franciscan Missionaries of Divine Motherhood, Teresian Sisters, Sisters of Mercy and Little Servants of Mary Immaculate. The sisters are using a radio talk show format in local languages to accurately inform people about the pandemic.

The radio programme was initially funded by Catholic Relief Services after which the sisters also received some funding from Alight. ${ }^{1}$ The programme was first aired on Yastani radio, a Catholic radio station in Lusaka. Besides radio, the sisters were also raising public awareness using brochures and posters. For example, the sisters partnered with Young Leaders Art Club that shared with them brochures and posters that proved helpful in their campaign. Given that the

1.Alight is a global aid group which works closely with refugees, trafficked persons, and economic migrants, to co-design solutions that help them build full and fulfilling lives. 
brochures and posters were in local languages, they were especially helpful in the rural communities where radio and TV networks are inaccessible (Gandiru, National Catholic Register 2020). The use of local language was a critical asset which the Catholic religious sisters exploited. This is in line with Luwaile's (2015:14) findings that languages in the Zambian cultural context have a significant role in making the community aware of RHAs. The appreciation of the Catholic religious sisters' use of local languages in communicating COVID-19 related information (Ajiambo, National Catholic Reporter, 2020) also affirms the potential of language to shape health and social behaviour.

The utilisation of radio, brochures and posters by the Roman Catholic religious sisters was also in line with the identified religious assets in the form of infrastructure and funding agencies (ARHAP 2005) that enabled them to play critical roles during pandemics. This also confirms the conclusions drawn by ARHAP (2006:21) that the Church plays a pivotal role in providing health knowledge, and Kabwe (2008) that disseminating knowledge was a religious asset which the church was using in Zambia. The church was understood as a social structure within which there is commitment to providing the community with knowledge pertaining to their health through sensitisation lessons that change the behaviour of the community (ARHAP 2006:49).

This use of the radio, brochures and posters also underscored the need to align awareness measures to the needs of the communities especially because in the rural areas, not all accessed smart phones and ICTs related technologies in ways which ignite African women theologies especially as related to social advocacy. This is because online interventions excluded large groups of disadvantaged communities with limited access to internet, electricity, mobile phones and other media technologies (Mwale \& Chita 2020:23). In this way, COVID-19 awareness was mediatised using traditional forms of media such as radio, brochures and posters as opposed to popular forms identified in emerging scholarship which include the use of TV, Facebook, WhatsApp, YouTube, Instagram, Twitter, Mixlr, Zoom and Vimeo among others (Aluko 2020).

The responses of the Catholic religious sisters also point to the utilisation of their RHAs in the form of organisational structures. For example, through their different apostolates, the religious sisters used their facilities and organisational structures to respond to the pandemic as was the case in their health and education centres, including the use of the Catholic media services. Thus, their long engagement in social service provision provided a springboard through which they could reach out to different groups of society. Besides, these facilities and programmes managed by individual congregations, the ZAS as a structure was also a platform through which the interventions were coordinated and implemented. As observed by ARHAP (2006:47), 'RHAs also include capabilities, skills, resources, links, associations, organisations and institutions located in a religious entity that could be tapped into for purposes of public health'. Therefore, the organisational structures of the sisters emerged as an asset that enabled the sisters to do theology in the community and stand with the needy in ways which transformed what it meant to be Church during a crisis'. As observed by Mendoza (2020:218), 'in so many ways, the lockdown unintentionally made the church question what it means to engage in mission and in the process, has made the church become more like the field hospital that Pope Francis envisions it to become'.

\section{Integration of COVID-19 awareness in existing programmes}

Besides using the different forms of media, facilities and the organisational structures, the Catholic religious sisters were also represented as having integrated COVID-19 awareness in their existing programmes. For example, the ZAS through the SCORE-ECD project, sensitised people about the virus in all areas where this project was being implemented (six sites). The funding was sourced through the Dominican sisters to help fight COVID-19 and prevent transmission among pregnant and lactating mothers (Okoth AMECEA News Thursday 04 June 2020). As such, supplies like handwashing buckets, face masks, gloves, printed materials for sensitisation programmes and handwashing soaps were distributed to all SCORE-ECD sites managed by nuns from different congregations.

Our sole message was about COVID-19 sensitisation, information sharing and understanding what the community knows about the virus....through interaction, they realised some people were ignorant about the deadly disease while others believed that Coronavirus is not real...we taught them how to make hand sanitisers, advised them to disinfect and keep surfaces clean and that they should not cough into their hands. Above all, we advised them to stay at home and avoid visiting others unless there is an urgent matter that cannot wait. Once they go out, they should follow prevention guidelines such as wearing of face masks, avoiding large crowds, shaking hands and always maintaining at least one-metre distance with the next person. (Okoth AMECEA News 04 June 2020:1)

Integrating COVID-19 in existing programmes by the Catholic religious sisters affirmed their flexibility to deliver programmes within the new context of the pandemic and tapping into their religious asset in the form of wide presence on the ground in many contexts where health crises are most urgent and having a public impact on health (ARHAP 2005). In this way, they embedded COVID-19 in their existing mission of providing education. As Ngundo and Wiggins (2017) observe:

[T] eaching is one of the basic apostolates with which nearly every religious institute is involved ... so that in collaboration with the governments many young people can rise and improve their lives. (p. 5)

This integration of COVID-19 in existing programmes further pointed to the sisters tapping into their RHAs in the form of spiritual encouragement (which ARHAP [2006:78] identifies as hope and compassionate care) which had the potential to 
promote human life and instil hope during a crisis. As argued by African theologians with reference to the HIV and AIDS pandemic, a theology of life (Dibeela 2007) and theology of compassion (Dube 2007) remained potential tools for responding to the COVID-19 pandemic.

\section{Donations to needy communities and vulnerable groups}

Additionally, the Catholic religious sisters were contributing to the fight of the pandemic through making assorted donations including critical equipment and supplies, such as face masks, soap and handwashing facilities and pamphlets with key COVID-19 messages. Apart from distributing essential supplies, the sisters were empowering girls to make face masks for their personal use and distribution to others. For example, the members of the Daughters of Mary Help of Christians in Zambia at City of Hope in Lusaka were:

$[H]$ elping the children adhere to the COVID-19 guidelines by facilitating girls in the program to make face masks for their personal use. The face masks made are also distributed to others while the girls also work on completing their school packages, studying, reading, and making handcrafts. (Maina, Association for Catholic Information in Africa 08 May 2020:2)

The Salesian-run City of Hope was established to meet the needs of youth and their families living in the most severe poverty in Lusaka in the mid-1990s (Salesians Missions Official News Service 2020).

Additionally, street children were among those with whom the religious sisters collaborated during the pandemic. For example, Mahyinda in the Daily Nation (27 April 2020) observed:

\begin{abstract}
Catholic sisters in Kitwe have extended a helping hand to the vulnerable to ameliorate their challenges in the wake of the COVID-19 outbreak. Sisters of St John the Baptist donated items which included hand soap, bathing soap, washing powder and bales of sugar worth K6, 566 for the vulnerable as a way of improving their livelihood... the Sisters of St John the Baptist were prompted to make a donation to the community because of the challenges people were facing in the face of the COVID-19. (n.p.)
\end{abstract}

These actions signify how religion could be a tool for collaborating with the state during the pandemic. As Phiri and Nadar (2010:93) observe, African women theologians seek solidarity with those who suffer marginalisation of every kind. This is also affirmed by del Castillo, Biana and Joaquin (2020:1-2) that aside from spiritually uplifting programmes, the Catholic Church also provided personal protective equipment and face masks to health workers, initiated feeding programmes to the poor and opened doors to the homeless.

The distribution of materials pointed to the Catholic religious' sisters use of the RHAs embedded in material support. Although it could not be detached from the biblical teaching on love and giving, it signified the Catholic religious sisters' appreciation of the challenges of most people being unable to afford to buy handwashing soap or sanitiser and facemasks in the communities. This was also in line with the conclusion drawn by Kabwe (2008) that offering material support by giving items that can be of use in the time of facing health challenges such as food, commodities and clothes was important in the Zambian context.

At the same time, the responses of the Catholic religious sisters pointed to their special focus on specific groups of people, especially the vulnerable in both the rural and urban areas. This is closely aligned to the Catholic social teaching on preferential option for the poor and quest to safeguard human dignity. This is also closely linked to the features of African women theologies as related to social advocacy (Haddad 2013:13) and recognition of human dignity (Adonis 2017:79). As observed by Ngundo and Wiggins (2017):

$[I] n$ the social domain, sisters also reach out to street children and mothers, physically and mentally challenged persons, orphaned children and single mothers based on Jesus' call for us to invite the poor, the crippled, the lame and the blind to the feast in Luke 14:13. (pp. 4-5)

By opting for the poor and ministering among the needy of society including those who could not benefit from COVID-19 related information that was often conveyed in English and on popular media platforms such as television and social media, the Catholic religious sisters tapped into their religious teachings. This affirms African women theologies anchored on the Bible as a source of theologising (Haddad 2013:13) in order to foster a theology of hope and life. This is deemed significant because the pandemic seemed to be another oppressor of the poor. As observed by Mendoza (2020) from the Philippine context:

[T] he pandemic slowed down the economic sector and the poor bore the brunt of the crisis and thus such a trying time called the Church to move by doing concrete acts of charity by sharing resources with those who need it the most. (p. 215)

The foregoing points to the Catholic religious sisters' use of both tangible and intangible RHAs in their contributions towards addressing the pandemic. These included the utilisation of their visible assets (in the form of facilities [(media platforms and organisational structures]), personnel, resources and material support) and invisible religious assets (in the form of capabilities, skills, links, associations, prayers, hope, care, knowledge dissemination and language among others). By so doing, women as exemplified by the Catholic religious sisters were contributing to shaping African women theologies in the Zambian context through fostering social advocacy, human dignity, drawing on Bible teachings as a source of theologising, and providing service in the community in ways which contributed towards a theology of hope and life during the pandemic.

The actions of the Catholic religious sisters were also grounded in their core mission of education, evangelisation and health. As observed by Ngundo and Wiggins (2017): 
$[T]$ he apostolates are driven by the teachings of Jesus; Jesus' call for us to invite the poor, the crippled, the lame and the blind to the feast is fulfilled in social work; Jesus' ministry of compassionate service of those ailing in body and spirit is fulfilled in health and the great commission is fulfilled in education and pastoral work. (pp. 4-5)

Mwaura (2015:93) also affirms that in the Catholic Church, justification for women's involvement in Missio Dei (God's Mission), interpreted as proclamation and witness, is derived from the scriptures as well as the social teachings of the church. Thus, religious teachings and scripture could be deemed not only as religious assets that were utilised in the Catholic religious sisters' responses to the pandemic, but were also the drive which informed the actions of the Catholic religious sisters during the pandemic.

Additionally, although the impact of the Catholic religious sister's work was not prominent in the media, going by Marshall and the World Politics Review's observation (2020, Doctrine 53) that millions of people worldwide look more to religious authorities than health officials for guidance on how to behave and what to believe during a crisis suggests that the contributions of the Catholic religious sisters towards addressing the pandemic could not be downplayed. Basker's (2020) title of a news feature story 'Who do people trust for coronavirus info in Zambia? It's the nuns on the radio' (National Public Radio 04 June 2020) also captures this asset inherent in the work of Catholic religious sisters and their possible impact on the community. This is also supported by the few sentiments that were captured in the media that people started phoning in to thank the sisters for using their languages during the radio awareness programmes and to share what changes they made to prevent the spread of the virus and keep themselves and their families safe (Ajaimbo 2020:5). This feedback suggests that the work of the Catholic religious sisters in addressing the pandemic was appreciated by the end user. Hence, the contributions of women religious workers during the pandemic could be deemed to be worth documenting in Zambian church history especially that of the Catholic religious sisters, who were quick to reorient their activities to the new situation presented by the pandemic. Most importantly, these contributions were to be understood in their own right as stressed by women theologians like Kanyoro (2002:23) that our [women's] stories are a basis for theology and that narratives of women not only complement African church history but also shifts women from being observers and victims into participants and actors in history (Adonis 2017:122).

\section{Conclusion}

This article explored the representation of the Roman Catholic religious sisters' responses to COVID-19 in the media in Zambia. In relation to the first objective (on how the Catholic religious sisters' responses to COVID-19 were represented in the media), the article concludes that the Catholic religious sisters' responses to COVID-19 in Zambia were covered by both Catholic related and public forms of media, and that the contributions of the religious sisters were more popular in Catholic related forms of media. Therefore, the Catholic tangible health assets were vital for communicating the ways in which the Catholic religious sisters had responded to the pandemic.

In relation to the second objective (on the nature of the responses of Catholic religious sisters to COVID-19), the article concludes that the responses were largely centred on mediatising public health awareness using traditional forms of media, integrating COVID-19 awareness in existing programmes and donations of assorted items to different vulnerable groups. These responses pointed to the Catholic religious sister's utilisation of their RHAs in the form of tangible assets (facilities and personnel, care or service, and material support) and intangible assets (volunteerism and education, or behaviour changes and the building of social capital in the form of hope or resilience). Thus, RHAs remained pillars not only for connecting religion and public health in the wake of COVID-19, but also for contributing towards addressing the new pandemic in the country.

Ultimately, given that the responses of women to the pandemic remained obscured in the wider narratives of the negative impact of the pandemic on women and religion's responses to COVID-19 in public discourses, the article advances that the Catholic religious sisters were active players in the prevention and management of COVID-19 and contributed to shaping African women theologies in the Zambian context. As such, there was a need for engendering religious responses to the pandemic, as the intersection of gender, religion and COVID-19 showed that not only were women the most affected as a vulnerable group but they were also active actors in combating the pandemic.

\section{Acknowledgements Competing interests}

The author declares that she has no financial or personal relationships that may have inappropriately influenced her in writing this article.

\section{Author's contributions}

N.M. is the sole author of this article.

\section{Ethical considerations}

This article followed all ethical standards for research without direct contact with human or animal subjects.

\section{Funding information}

This research received no specific grant from any funding agency in the public, commercial or not-for-profit sectors.

\section{Data availability}

Data sharing is not applicable to this article as no new data were created or analysed in this study. 


\section{Disclaimer}

The views and opinions expressed in the article are those of the author and do not necessarily reflect the official position of any affiliated agency of the author.

\section{References}

Adonis, M.M., 2017, 'An African women's theological analysis of a development programme: "Churches, channels of hope"', Masters dissertation, Stellenbosch University.

African Religious Health Assets Programme (ARHAP), 2005, 'Background and a conceptual framework for contributors', in An invitation: International case study colloquium, pp. 1-3, African Religious Health Assets Programme, Pretoria, July 13-16, 2005.

African Religious Health Assets Programme (ARHAP), 2006, Appreciating assets: The contribution of religion to universal access in Africa, Report for the World Health Organization, Cape Town

Ajaimbo, D., 2020, Q \& A with Sr. Astridah Banda, 'unsung hero' for educating on COVID-19, pp. 1-11, Global Sisters Report, 17 November, viewed 27 July 2020, from https://www.globalsistersreport.org.

Alight, n.d., 'About Us', viewed 27 July 2021, from https://wearealight.org.

Aluko, O.P., 2020, 'COVID-19 pandemic in Nigeria: The response of the Christian Church', African Journal of Biology and Medical Research 3(2), 111-125.

Barker, C., Pistrang, N. \& Elliott, R., 2002, Research methods in clinical psychology: An introduction for students and practitioners, John Wiley and Sons, Chichester.

Barnett, T. \& Whiteside, A., 2006, AIDS in the twenty-first century: Disease and globalisation, 2nd edn., Palgrave Macmillan, New York, NY.

Basker, P., 2020, Who do people trust for coronavirus info? In Zambia, it's nuns on the radio, National Public Radio, 04 June, viewed 27 July 2020, from https://www.npr. org/sections/goatsandsoda/2020/06/04/865520129/radio-nun-with-a-covid-19show-we-sisters-are-a-force-to-reckon-with

Bryman, A., 2004, Social research methods, Oxford University Press, Oxford.

Chakwe, M., 2020, 'Catholic bishops set up COVID-19 fund', The Mast Newspaper, 17 April, viewed 28 July 2020, from https://www.themastonline.com/2020/04/17/ catholic-bishops-set-up-covid-19-fund/.

Chitando, E., 2007, Living with Hope: African Churches and HIV/AIDS 1, World Council of Churches, Geneva.

Cochrane, J.R., Schmid, B. \& ARHAP, 2004, African Religious Health Assets Programme (ARHAP), ARHAP Workshop Report, Cape Town, June 06-08.

Cohen, L., Manion, L. \& Morrison, K., 2007, Research methods in education, Routledge Falmer, London.

Congregation for the Institutes of Consecrated Life and Societies of Apostolic Life, 2008, The service of authority and obedience: Faciem tuam, Domine, requiram Paulines Publications Africa, Nairobi.

Coulson, J., Clarke, R. \& Fall, M.M., 2020, 'COVID-19 jeopardises progress made towards protecting women and girls from violence,' Statement to mark International Day of the African Child, 15 June, viewed 28 July 2020, from https:// www.unicef.org/esa.

Del Castillo, F.A., Biana, H.T. \& Joaquin, J.J.B., 2020, 'ChurchlnAction: The role of religious interventions in times of COVID-19', Journal of Public Health 42(3), 633-634.

Dibeela, P.M., 2007, Module 6: A theology of life in the HIV \& AIDS context, in theology in the HIV \& AIDS era series, M.W. Dube (ed.), World Council of Churches, Geneva.

Dube, M.W., 2007, Module 7: A theology of compassion in the HIV \& AIDS era, in theology in the HIV \& AIDS era series, M.W. Dube (ed.), World Council of Churches, Geneva.

Eze, C., Lindegger, G.C. \& Rakoczy, S., 2015, 'Catholic religious sisters' identity dilemmas as committed and subjugated workers: A narrative approach', Review of dilemmas as committed and subjugate
Religious Research 57(3), 397-417.

Gandiru, G., 2020, 'Catholic religious on the front lines combat spread of COVID-19 in Africa,' The National Catholic Register, viewed 27 July 2020, from www.ncregister. com/news.

Geertsema, M., 2008, 'Women making news: Gender and media in South Africa', Global Media Journal 7(12), 1-8.

Hackett, R., Melice, A., Van Wolputte, S. \& Pype, K., 2014, 'Interview: Rosalind Hacket reflects on religious media in Africa', Social Compass 61(1), 67-72.

Haddad, B., 2011, Religion and HIV and AIDS: Charting the Terrain, University of KwaZulu-Natal Press, KwaZulu-Natal.

Haddad, B., 2013, 'The South African women's theological project: Practices of solidarity and degrees of separation in the context of the HIV epidemic', Religion and Theology 20, 2-18.

Hinfelaar, H.F., 2004, History of the Catholic Church in Zambia, Bookworld Publishing House, Lusaka.

Iyakaremye, I., 2015, 'Neglecting religious health assets in responding to HIV and AIDS. An assessment of the response of the Free Methodist Church of Southern Africa to HIV and AIDS', Missionalia 43(1), 23-44. https://doi. org/10.7832/43-1-80
Jaja, I.F., Anyanwu, M.U. \& Iwu Jaja, C.J., 2020, 'Social distancing: How religion, culture and burial ceremony undermine the effort to curb COVID-19 in South Africa', Emerging Microbes \& Infections 9(1), 1077-1079. https://doi.org/10.1080/22221 Emerging Microbes
751.2020 .1769501

Kabwe, M.K., 2008, 'Local churches and health: An examination of four local churches' contribution to direct health out-comes on the Copperbelt province of Zambia', Masters dissertation, University of KwaZulu-Natal.

Kanyoro, M., 2002, Introducing feminist cultural hermeneutics: An African perspective, Sheffield Academic Press, New York, NY.

Kothari, C.R., 2004, Research methodology: Methods and techniques, New Age International, New Delhi.

Landman, C., 2005, 'Spiritual care-giving to women affected by HIV/AIDS,' in I.A. Phiri, B. Haddad \& M. Masenya (eds.), African women, HIV/AIDS and faith communities, pp. 189- 208, Cluster Publications, Pietermaritzburg.

Lichtenstein, A., Ajayi, R. \& Egbunike, N., 2020, Across Africa, COVID-19 heightens tension between faith and science. Pandemic Response and Religion in the USA tension between faith and science. Pandemic Response and Religion in the USA: Doctrine. 1, viewed $28 \mathrm{July} 2020$, from https://oxfamblogs.
covid-19-heightens-tension-between-faith-and-science/.

Luwaile, A., 2015, 'Faith and health: An appraisal of the work of the African Religious Health Assets Program (ARHAP) among faith communities in Zambia', Masters dissertation, University of KwaZulu-Natal.

Mahuku, E., Yihun, K.L., Deering, K., \& Molosani, B., 2020, 'CARE Rapid Gender Analysis for COVID 19: East, Central and Southern Africa,' Care International Report, viewed 27 July 2020, from https://www.careevaluations.org/evaluation/ care-rapid-gender-analysis-for-covid-19-east-central-and-southern-africa/.

Maina, M., 2020. 'How Salesian sisters in Zambia are supporting vulnerable children amid COVID-19', Association for Catholic Information in Africa, 08 May, viewed 02 June 2021, from https://www.aciafrica.org/news/1299/how-salesian-sistersin-zambia-are-supporting-vulnerable-children-amid-covid-19.

Manyinda, S., 2020, 'Catholic sisters aid street kids', Daily Nation Newspaper, 27 April, viewed 25 June 2020, from https://dailynationzambia.com/2020/04/27/catholicsisters-aid-street-kids/.

Marshall, K. \& World Politics Review, 2020, What religion can offer in the response to COVID-19? Pandemic response and religion in the USA: Doctrine. 53, viewed 02 June 2021, from https://www.worldpoliticsreview.com/articles/28789/whatreligion-can-offer-in-the-response-to-covid-19.

Mendoza, R.C., 2020, 'What if: COVID-19 in the Philippines in the light of the catholic social tradition', Journal of Dharma: Dharmaram Journal of Religions and Philosophies 45(2), 201-222.

Ministry of Health, 2020, Press briefing on COVID-19 and Additional preventive and control measures, 17 March, Lusaka, viewed 20 June 2020, from https://znphi. control measures, 17 March, Lusaka, viewed 20 June 2020, from https://znphi. co.zm/news/press-statement-on-covid-19-and-additional-preventive-and-
control-measures-introduced-by-the-government-of-the-republic-of-zambia/.

Mouton, J., 2001, How to succeed in your master's \& doctoral studies: A South African guide and resource book, Van Schaik Publishers, Pretoria.

Mulenga, E.M. \& Marbán, J.M., 2020, 'Is COVID-19 the gateway for digital learning in mathematics education?', Contemporary Educational Technology 12(2), ep269. https://doi.org/10.30935/cedtech/7949

Mwale, B., 2020, 'COVID-19: ZCCB Call on Private Sector to help fight disease', Zambia National Broadcasting Corporation, 14 April

Mwale, N. \& Chita, J., 2016, 'Religion and the media: The portrayal of prophecy in the Zambian Media', in H. Kroesbergen (ed.), Prophecy today: Reflections from a Southern African context, pp. 41-63, Christian Literature Fund, Wellington.

Mwale, N. \& Chita, J., 2020, 'Higher education and programme delivery in the context of COVID-19 and institutional closures: Student responses to the adoption of e-learning at a public university in Zambia', in N. Ndimande-Hlongwa, L. Ramrathan, N. Mkhize \& J.A. Smit (eds.), Technology-based teaching and learning in higher education during the time of COVID-19, pp. 9-33, CSSALL Publishers, Durban.

Mwaura, P.N., 2015, 'The circle of concerned African women theologians and their engagement in public theology: A pathway to development', Pathways to African Feminism and Development, Journal of African Women's Studies Centre 1(1) 90-104.

Ngundo, B. \& Wiggins, J., 2017, Women religious in Africa, Centre for Applied Research in the Apostolate Special Report, pp. 1-8, Georgetown University, Washington, DC.

Nkomeshya, U., 2020, 'Churches resist Lungu's reopening order', News Diggers, 25 April, viewed 24 June 2020, from https://diggers.news/local/2020/04/25/ churches-resist-lungus-reopening-order/.

Okoth, J.A., 2020, 'Awareness creation on COVID-19: Key activity for religious nuns in Zambia', AMECEA News, 04 June, viewed 28 July 2020, from http://amecea. blogspot.com/2020/06/zambia-awareness-creation-on-covid-19.htm .

Olivier, J., 2011, 'Religion and policy on HIV and AIDS: A rapidly shifting landscape', in B. Haddad (ed.), Religion and HIV and AIDS: Charting the terrain, pp. 81-104, University of KwaZulu-Natal Press, Scottsville.

Olivier, J., Cochrane, J. \& De Gruchy, S., 2012, 'Mapping religious community health assets and initiatives: Lessons from Zambia and Lesotho', in J. Olivier \& Q. Wodon (eds.), Mapping, cost, and reach to the poor of faith-inspired health care providers in Sub-Saharan Africa, HNP Discussion Paper, pp. 52-61, World Bank, Washington, DC

Phiri, I.A. \& Nadar, S., 2010, 'African women theologies', in B. Stinton Diane (ed.), African theology on the way: Current conversations, pp. 90-100, SPCK, London.

Prempeh, C., 2020, Religion and the state in an episodic moment of COVID-19 in Ghana, Social Sciences and Humanities Open, viewed 30 June 2020, from http:// ssrn.com. 
Salesians Missions Official News Service, 2020, 'Zambia: City of Hope supports at risk girls and mothers through the coronavirus pandemic', Mission Newswire, 06 May, viewed 20 June 2020, from https://missionnewswire.org/zambia-cityof-hope-supports-at-risk-girls-and-mothers-through-the-coronaviruspandemic/.

Scott, J., 1990, A matter of record: Documentary sources in social research, Polity Press, Cambridge.

Sepeti, T., 2008, 'The theological impact of the handmaid sisters on the community of Mpunde Mission, in Kabwe Zambia', Masters dissertation, University of South Africa.
Sintema, E.J., 2020, 'Effect of COVID-19 on the performance of grade 12 students: Implications for STEM education', Eurasia Journal of Mathematics, Science and Technology Education 16(7), em1851. https://doi.org/10.29333/ejmste/7893

The Conrad N. Hilton Foundation's Catholic Sisters Initiative, 2017, 'A case study: Catholic sisters in Zambia', Centre for Religion and Civic Culture, University of California, Los Angeles, CA.

Wildman, W.J., Bulbulia, J., Sosis, R. \& Schjoedt, U., 2020, 'Religion and the COVID-19 pandemic', Religion, Brain \& Behaviour 10(2), 115-117.

Zambia Association of Sisterhoods, n.d., 'Who we are', viewed 02 June 2021, from https://zamsisters.com/. 